\title{
LACK OF KNOWLEDGE ABOUT ORGAN DONATION AND TRANSPLANTATION AMONG DENTAL STUDENTS
}

A falta de conhecimento sobre doação e transplante de órgãos entre estudantes de odontologia

Falta de conocimiento sobre donación y trasplante de órganos entre estudiantes de odontología

\section{Liliane Lins Kusterer ${ }^{1}$, Caroline Gomes Carvalho ${ }^{2}$, Marina Gallottini ${ }^{3}$, Karin Sá} Fernandes $^{3}$, Patrícia Sanches Kerges Bueno ${ }^{2}$, Heitor Marques Honório ${ }^{2}$, Beatriz Roque $\mathrm{Kubata}^{4}$, Marilena Chinali Komesu ${ }^{4}$, Paulo Sérgio da Silva Santos ${ }^{* 2}$

${ }^{1}$ Dentistry, Federal University of Bahia, Salvador, BA, Brazil.

${ }^{2}$ Dentistry, Bauru School of Dentistry, University of São Paulo, Bauru, SP, Brazil.

${ }^{3}$ Dentistry, School of Dentistry, University of São Paulo, SP, Brazil.

${ }^{4}$ Dentistry, Ribeirão Preto School of Dentistry, University of São Paulo, Ribeirão Preto, SP, Brazil.

* Corresponding author: Department of Surgery, Stomatology, Pathology and Radiology, Bauru School of Dentistry. Alameda Octávio Pinheiro Brisola, 9-75, Vila Universitária - 17012-191 - Bauru - SP - Brazil. Telephone: (14)3226-6113 FAX: (55) 14-32358254.email: paulosss@fob.usp.br

Artigo recebido em 09/04/2020 aprovado em 10/09/2020 publicado em 05/03/2020.

\section{RESUMO}

Este estudo avaliou o nível de conhecimento dos estudantes de odontologia sobre doação e transplante de órgãos, em quatro instituições de ensino superior (IES) brasileiras. O estudo foi realizado com 477 acadêmicos do primeiro e último ano da graduação, durante um ano. Foi aplicado um questionário padronizado contendo questões sobre doação e transplantes de órgãos, conceito de morte encefálica, atividades escolares e aulas sobre o tema, intenção de doar órgãos e conhecimentos aplicados à odontologia na área de transplantes. Por estatística descritiva as diferenças entre os grupos foram analisadas pelo teste qui-quadrado. Apenas $84(18 \%)$ estudantes relataram já ter participado de alguma aula sobre transplante de órgãos. Trezentos e vinte (67\%) estudantes relataram conhecer a definição de morte encefálica, mas desconheciam como é realizado o diagnóstico $(\mathrm{p}=0,148)$. Havia desconhecimento quanto aos cuidados especiais aos possíveis doadores de órgãos $(\mathrm{p}=0,148)$ e a abordagem familiar em caso de morte encefálica $(\mathrm{p}=0,561)$. Esse estudo constatou a falta de conhecimento sobre doação e transplante de órgãos entre estudantes de graduação de Odontologia nas quatro IES investigadas. Sugere-se a implementação curricular sobre a temática abordada, a fim de preparar esses profissionais a integrar uma equipe de transplante.

Palavras-chave: Transplante de órgãos, Estudantes de Odontologia, Educação em Odontologia.

\section{ABSTRACT}

The present study evaluated dental students at four Brazilian higher education institutions (HEIs) for their level of knowledge regarding organ donation and transplantation, and involved 477 students in either their first or last year of schooling, from March 2011 until June 2012. A standardized questionnaire was used, which contained questions about organ donation and transplants, the concept of brain death, school activities and classes on organ donation, students' intentions to donate organs, and transplantation knowledge as it applies to the field of dentistry. Using descriptive statistics, the differences between the groups were analyzed using the chi-square test. Only 84 (18\%) students reported having participated in an organ transplant class, although $320(67 \%)$ students reported knowing the definition of brain death but were unaware of how the diagnosis was made $(p=0.148)$. There was a lack of knowledge regarding special care for possible organ donors $(p=0.148)$, as well as for the family approach in cases of brain death $(p=0.561)$. The present study found a lack of knowledge about organ donation and transplantation 
among undergraduate dental students in the four HEIs investigated, suggesting that the curricular implementation of lessons focusing on organ donation and transplantation should be addressed in order to prepare these professionals to function as part of a transplant team if needed.

Keywords: Organ Transplantations, Students, Dental, Education, Dental.

\section{RESUMEN}

Este estudio evaluó el nivel de conocimiento de los estudiantes de odontología sobre la donación y el trasplante de órganos, en cuatro instituciones de educación superior (IES) brasileñas. El estudio se realizó con 477 estudiantes del primer y último año de graduación, durante un año. Se aplicó un cuestionario estandarizado que contenía preguntas sobre donación de órganos y trasplantes, concepto de muerte cerebral, actividades escolares y clases sobre este tema, intención de donar órganos y conocimiento aplicado a la odontología en el campo del trasplante. Utilizando estadísticas descriptivas, las diferencias entre los grupos se analizaron mediante la prueba de chicuadrado. Solo 84 (18\%) estudiantes informaron haber participado en una clase de trasplante de órganos. Trescientos veinte (67\%) estudiantes informaron conocer la definición de muerte cerebral, pero no sabían cómo se hace el diagnóstico $(p=0.148)$. Hubo una falta de conocimiento sobre la atención especial para posibles donantes de órganos $(p=0.148)$ y el enfoque familiar en caso de muerte cerebral $(p=0.561)$. Este estudio encontró una falta de conocimiento sobre la donación y el trasplante de órganos entre los estudiantes universitarios de odontología en las cuatro IES investigadas. Se sugiere la implementación curricular sobre el tema abordado, a fin de preparar a estos profesionales para integrar un equipo de trasplante.

Descriptores: Transplante de órganos, Estudiantes de Odontología, Educación en Odontología.

\section{INTRODUCTION}

Organ donation comprises a multifactorial choice involving social, cultural, legal, ethical, and medical aspects. Donation rates vary widely among Brazilian states, with as many as $75 \%$ of families refusing to donate organs and tissues in some states. As a result, the number of patients needing transplants is substantially higher than the number of available donors. According to the Brazilian Transplantation Registry (Brazilian Transplantation Registry, 2017), in 2017, the estimated annual needed and available number of transplants was 39.362 and 23.742, respectively.

Organ Transplantation in Brazil is regulated by State Law, which was established in 1997 (Brazil, 1997). The laws regarding organ donation and transplantation reflect Brazilian cultural values: the authorization for brain-death organ donation is obtained with the family's written consent, and the living-donor transplantation between unrelated persons needs judicial authorization (Brazil, 1997). The diagnosis of brain death is legally recognized and is based on clinical and complementary examinations, which provide evidence of the absence of cerebral blood flow and electrical activity (Federal Council of Medicine, 1997).

The Ministry of Health implemented the National Transplant System (SNT), which centralized the State Health Secretariats, creating a unique regional list supervised by the Public Ministry. Brazilian states regulate the registration of transplantation services and specialized teams, establish funding criteria, and encourage the best ethical and technical conduct for the full, equitable operation of the system. The Public Health System funds more than $97 \%$ of transplants performed in Brazil as well as subsidizing immunosuppressive drugs for transplant patients (Brazil, Ministry of Health, 2017).

Undergraduate courses should include lessons regarding organ transplantation (Siebelink et al., 2017) since the increasing number of transplant patients in recent years has impacted oral and dental services. Living-donor transplant patients need comprehensive and regular dental care during pre- and post-transplant 
periods, making it prudent to have dentists a part of the multidisciplinary transplant team (Gaspar et al., 2015; Santos and Mello, 2018). Oral infection represents a risk to transplantation since more than $80 \%$ of transplanted patients develop at least one infection (Brazil, Ministry of Health, 2017), and infections are the main cause of death (40\%) after transplantation (Eun, 2013). Dental management should include diagnostic, preventive, and curative approaches, including foci elimination while considering systemic disorders and immunosuppression of the patient (Santos et al., 2009; Deepika and Lingappa, 2015). In some conditions, dental treatment may decrease morbimortality in transplant patients (Lins et al., 2011).

Several factors may be involved in the consent to organ donation, such as cultural issues, lack of public information, and even lack of knowledge among healthcare professionals. The attitude of healthcare workers may prompt organ donation, and is important to the success of the organ donation process, since an adequate healthcare approach may influence donor family decisions. Unfortunately, during undergraduate medical, dental, and nursing courses, little knowledge of organ donation and transplantation is acquired $(\mathrm{Goz}$, Goz, and Erkan, 2006). Most of the Brazilian studies published on this topic were conducted with medical students or physicians in a single-center hospital or medical school (Lima et al., 2010; Batista and LinsKusterer, 2010; Reins et al., 2013). When considering the field of dentistry, literature regarding transplantation is even scarcer, since dental professionals have only become part of the transplant team in recent years. The literature reviewed in the present study revealed that no multicenter research has been conducted on dental students' knowledge regarding organ donation in Brazil.
The goal of the present study, therefore, was to assess the level of knowledge regarding organ donation and transplantation in students from four Brazilian dental schools.

\section{MATERIAL AND METHODS}

The present study was conducted at the following schools: Bauru School of Dentistry, Ribeirão Preto School of Dentistry (FORP/USP), School of Dentistry of the University of São Paulo (FOUSP), and School of Dentistry of the Federal University of Bahia (FOUFBA). A cross-sectional, questionnaire-based study was conducted among 477 undergraduate dental students at these colleges from March 2011 to June 2012. Each academic institution applied the questionnaires at different time points, justifying the 16-month time frame. The sample population was composed of academics enrolled in their first and last year of dental courses. For the present study, we used a standardized questionnaire containing questions regarding demographic data, and multiple-choice questions about donation and organ transplantation, the concept of brain death, school activities and classes pertaining to organ donation, students' intentions to donate organs, and other knowledge regarding transplantation as it applies to dentistry. The questionnaire was created after a scientific literature review, using LILACS, SciELO, and MEDLINE databases and articles published between 1998 and 2020 that contained the following keywords: transplant, brain death, organ donation, and tissue donation.

The questionnaire, with a duration not longer than 15 to 20 minutes, was administered to dental students either prior to or just any given day during the semester. A convenience sample technique was used, in which all students present in the classroom on the 
day the questionnaire was administered agreed to participate in the research. All participants were informed and signed a consent form approved by the Ethics Board of all institutions presented in this study. The present study was approved by the Institutional Committee for Ethics in Research, Case No. 061/2011, following the Declaration of Helsinki 2013 and the National Council Resolution 466/12. Statistical analysis was performed using the Statistical Package for the Social Sciences SPSS v. 21. Frequencies were described and differences were analyzed by the chisquared test or by Fisher's test when appropriate. A pvalue $<0.05$ was considered to be statistically significant.

\section{RESULTS AND DISCUSSION}

Of the 477 participants, 59 (12.4\%) undergraduate dental students attended FOB/USP, 126 (26.4\%) attended FORP, 166 (34.8\%) attended FOUSP, and 126 (26.4\%) attended UFBA. The mean age was 21.9 years, with a range of 18 to 35 .

Students in their first or last year did not differ significantly $(P=0.27)$ in the self-assessment questionnaire about organ transplantation knowledge. The majority of the students considered their level of knowledge to be good (77.5\%), followed by those that considered their level of knowledge to be bad (16.2\%), and those that considered it excellent $(6.3 \%)$. The proportions of student organ donors were similar $(P=$ 0.199 ) for students in their first or last year, $64.8 \%$ and $70.6 \%$, respectively. However, those in their last year tended to be more prone to considering living donation compared to those in their first year, $70.8 \%$ and $54.5 \%$, respectively $(P=0.017)$.

Table 1 summarizes the primary results regarding the dental students' knowledge of and attitude toward organ donation and transplantation during their first or last year of school. Of the students that completed the questionnaire, 84 (17.6\%) reported having already attended to a class pertaining to organ transplantation, most of them during the last year of the program $(P=0.001)$. Students reported knowing the definition of brain death but did not know how a diagnosis was made $(P=0.148)$. Neither group knew about the maintenance care required for potential organ donors $(P=0.148)$, or how to approach the family about donation in the case of brain death $(P=0.561)$. In regards to the questions about living-donor transplants, the minority of students considered living donations to include the intestine $(6.1 \%)$, pancreas $(7.3 \%)$, and cornea $(20.7 \%)$, revealing a deficiency in teaching and training dental students in the field of organ donation and transplantation.

Of the sample population, 157 (32.9\%) of the dental students preferred not to be organ donors, 80 (46.8\%) of whom feared organ trafficking. Of these 80 students, $39(48.81 \%)$ were in their first year and 41 $(51.2 \%)$ were in their final year. Only $30(6.3 \%)$ students admitted to not having enough knowledge about donation and transplantation to justify not being a donor, while 7 (1.5\%) declined for religious reasons, and $67(13.4 \%)$ never thought about it. Of the students questioned, only 68 (14.2\%) declared being blood donors. Of the 477 students who took the questionnaire, $345(72.3 \%)$ answered the questions about the phase(s) of the transplantation which would involve a dentist. Of these 345 students, 190 (55.1\%) correctly identified all phases of the transplantation process, however, 40 (11.6\%) identified the phase before transplantation, 15 (4.3\%) during transplantation, 40 (11.6\%) after transplantation, and 60 (17.3\%) did not give a correct answer.

The success of transplants depends on societal education concerning the ethical issues involved in the 
process of donation and transplantation, as well as an adequate training of healthcare professionals. Even with the organization and administrative security of the transplant process provided by the Brazilian State, the number of people on the waitlist for an organ far exceeds the number of available organs (Brazilian Transplantation Registry, 2017). The appropriate education of undergraduate healthcare students represents an important factor that may decrease the waitlist for transplantation.

This is the first multi-center Brazilian study, conducted in both Northeast and Southeast Brazil that has investigated undergraduate dental students' knowledge concerning organ donation and transplantation. A PubMed search performed in July 2020, using the descriptor "students, dental" and "organ transplantation" revealed only four articles involving these topics: two carried out on dental students in India (Srinivasula et al., 2018; Chakradhar et al., 2016), one carried out on medical and nursing students in Italy (Fontana et al., 2017), and one carried out on medical, nursing, and dental students in Turkey (Goz, Goz, and Erkan, 2006).

Table 1 - Knowledge of and attitudes about organ donation and transplantation based on the year of study of 477 dental students from four Brazilian universities, 2011-2012.

\begin{tabular}{lccccc}
\hline Knowledge/attitude & \multicolumn{2}{c}{ First year } & \multicolumn{2}{c}{ Last year } & \\
& yes & No & Yes & No & P \\
& $\mathrm{n}(\%)$ & $\mathrm{n}(\%)$ & $\mathrm{n}(\%)$ & $\mathrm{n}(\%)$ & \\
\hline Attended a class on organ transplantation & $27(8,8)$ & $279(91,2)$ & $57(33,5)$ & $113(66,5)$ & $0,001^{*}$ \\
Brain death definition & $194(64.0)$ & $109(36.0)$ & $126(74,1)$ & $44(25,9)$ & $0,024^{*}$ \\
Brain death diagnosis & $50(16,5)$ & $253(83,5)$ & $37(21,9)$ & $132(78,1)$ & $0,148^{*}$ \\
Organ donor & $197(64,8)$ & $107(35.1)$ & $120(70,6)$ & $50(29.4)$ & $0,199^{*}$ \\
Living organ donor & $165(54.5)$ & $138(45.5)$ & $112(70,8)$ & $58(34.1)$ & $0.017^{*}$ \\
Maintenance care of potential organ & $65(21,2)$ & $242(78,8)$ & $38(22,4)$ & $132(77,6)$ & $0,764^{*}$ \\
donors knowledge & & & & & \\
Comunicating family about Brain Death & $156(54.0)$ & $133(46.0)$ & $87(51,2)$ & $83(48,8)$ & $0,561^{*}$ \\
and organ donation & & & & & \\
Answers about living organ donation & & & & & \\
Living donation of intestine & $3(0,8)$ & $303(99.2)$ & $9(5.3)$ & $161(94.7)$ & $0,011^{* *}$ \\
Living donation of pancreas & $6(2.0)$ & $300(98.0)$ & $9(5.3)$ & $161(94.7)$ & $0,057^{* *}$ \\
Living donation of cornea & $29(9.5)$ & $275(90.5)$ & $19(11.2)$ & $151(88.8)$ & $0,571^{*}$ \\
\hline
\end{tabular}


The present study showed that dental students in Brazil receive little education regarding organ donation and transplantation, including information about brain death. These results are in-line with other studies that have used questionnaires to assess the knowledge of students in healthcare on this subject (Bitencourt et al., 2007; Lima et al., 2010; Reis et al., 2013; Dibo et al., 2017; Fontana et al., 2017; Srinivasula et al., 2018; Tackmann, Kurz, and Dettmer, 2020).

Only $18 \%$ of the 477 students who completed the questionnaire reported having already attended a class on the topic of organ donation and transplantation, suggesting that this subject is not well addressed in the curriculum of dental schools. The limited knowledge of the dental program undergraduates in our study reinforces the evidence of an inadequate approach regarding donation and transplantation of the current dental curriculum. Other Brazilian studies evaluating undergraduate medical students have also highlighted the lack of education and training regarding organ donation and transplantation during medical courses (Bitencourt et al., 2007; Reis et al., 2013; Dibo et al., 2017). However, one interventional study reported that a single class on organ donation can improve the knowledge, attitudes, and practices of dental students in that regard (Srinivasula et al., 2018), corroborating the study by Jain et al. (2019), which implemented a program-based educational intervention through an electronic presentation and participatory dialogue. Extracurricular educational programs regarding organ donation and transplantation, such as academic leagues, might increase students' knowledge and training in these areas (Almeida et al., 2011). Subsequently, this additional education may help to avoid misconceptions and facilitate communication between patients, family members, and healthcare workers about organ donation (Tackmann, Kurz, and Dettmer, 2020).

Of the 477 dental students, only $66.5 \%$ were organ donors. These findings are in accordance with other studies that have evaluated the knowledge of medical students in Brazil (Bitencourt et al., 2007; Batista and Lins-Kusterer, 2010). In the present study, some students have justified not being an organ donor because they fear organ trafficking, for religious reasons, due to lack of knowledge about the subject, or because they have just never thought about it.

Current literature describes some regarding the diagnosis of brain death and organ donation which may be difficult. These factors include ethical, moral, religious, and spiritual aspects, technical and scientific knowledge, institutional limitations, and conflicts of interest (Bitencourt et al., 2007). Only 1.5\% of the students who participated justified not being a donor 77 due to religious reasons; however, a recent study (Santos et al., 2016) that investigated the knowledge and opinions of Brazilian medical students regarding the ethical aspects of transplantation evidenced that more than $80 \%$ of first- and fourth-year medical students believe that religion influences organ donation. Although the issue of religion may be related to the belief that the act of organ donation is an altruistic sacrifice, although most dental students believe that their religion would allow organ donation (Srinivasula et al., 2018).

Some of the dental students' answers about living organ donation evidenced a lack of knowledge about donation, as the intestine $(6.1 \%)$, pancreas (7.3\%), and cornea (20.7\%) were considered by some dental students to be the likely choices for living donations. The present research showed some deficiencies in dental school curricula, specifically in the area of organ donation and transplantation, which may contribute to the improvement of academic 
graduation requirements and curricula reform. Our results emphasize the importance of this knowledge on the part of healthcare students because once properly educated, they can provide improved communication between medical institutions, patients, and their families, and hopefully a subsequent increase in organ donation rates. Family involvement and decisionmaking are important to the increase in donation rates since communication affects family decision-making and/or decreases family opposition to organ donation in cases of undeclared wills (Fontana et al., 2017; Miller and Breakwell, 2018; Pessoa et al., 2020; Robba, Fossi, and Citerio, 2020).

Patients undergoing organ transplants need to be cared for during the entire process, both before and after the transplant (Santos et al., 2009; Lins et al., 2011), which makes it important to integrate a multidisciplinary transplant team. Only 190 (39.8\%) of the 477 students identified all the phases of the transplantation process as involving dentistry. This finding reinforces the necessity of implementing dental school curricula in undergraduate dental schools, particularly regarding organ donation and transplantation.

The present study did have some limitations. As an adequate sample size was not calculated prior to the onset of the study, we took a convenience sample, and there was some difficulty in getting a sufficient sample of last year students. On the other hand, this is the first multicenter study in Brazil that evaluated dental students' knowledge about organ donation and transplantation. Additional investigations are needed to assess the knowledge of students in other dental schools in Brazil.

\section{CONCLUSION}

Most of the students that participated in this study did not have education regarding organ donation and transplantation during their undergraduate education; however, the true involvement of dental professionals on the transplant team is unknown, as is their involvement in the management of these patients. Given these circumstances, implementing a curriculum regarding organ donation and transplantation to prepare dental professionals to integrate into national transplant teams would be beneficial. This strategy would contribute to the comprehensive multidisciplinary care of transplant patients.

\section{ACKNOWLEDGMENTS}

We would like to thank Editage (www.editage.com) for English language editing.

Todos os autores declararam não haver qualquer potencial conflito de interesses referente a este artigo.

\section{REFERENCES}

ALMEIDA, R.A.; QUIREZE, C. JR; DE FARIA, 78 W.M.; DOS SANTOS, D.F.; DIAS, R.V.; MAYNARDE, I.G. Organ donation and transplantation from medical students' perspective: introducing the experience from an academic league in Brazil. Transplant Proc. v. 43, p.1311-2, 2011.

BATISTA， C.R.; LINS-KUSTERER， L.E.F.L. Knowledge of medical students on organ donation and transplantation. JBT J Bras Transpl. v.13, p.12811328,2010

BITENCOURT, A.G.; NEVES, F.B.; DURÃES, L.; NASCIMENTO, D.T.; NEVES, N.M.; TORREÃO, L. DE A; AGARENO, S. Evaluation of medical students knowledge on brain death. Rev Bras Ter Intensiva v.19, p.144-150, 2007.

Brazil. Ministry of Health. National Transplant System. Available in: http://portalsaude.saude.gov.br/index.php/oministerio/principal/secretarias/sas/transplantes/siste ma-nacional-de-transplantes Accessed Aug 26, 2017.

Brazil. Presidency of Republic. Law $\mathrm{n}^{\mathbf{0}}$ 9.434, 4 Feb 1997. Available in: http://www.planalto.gov.br/ccivil_03/leis/L9434.htm Acessed Aug 26, 2017.

CHAKRADHAR, K.; DOSHI, D.; SRIKANTH, R. B.; KULKARNI, S.; PADMA, R. M.; SRUTHI, R. S. Knowledge, Attitude and Practice Regarding Organ 
Donation among Indian Dental Students. Int J Organ Transplant Med. v.7, p.28-35, 2016.

DEEPIKA, N.; LINGAPPA, A. Oral manifestations in transplant patients. Dent Res J (Isfahan) v.12, p.199208, 2015.

DIBO, F.H.A.; GRAVENA, Â.A.F.; DE FREITAS, R.A.; DELL'AGNOLO, C.M.; DE ALMEIDA BENGUELLA, E.; PELLOSO, S.M.; BARROS CARVALHO, M.D. Brain Death: Knowledge of Future Brazilian Physicians. Transplant Proc. v.49, p.750-755, 2017.

EUN, S.C. Composite tissue allotransplantation immunology. Arch Plast Surg. v.40, p.141-153, 2013.

Federal Councilof Medicine. Resolution CFM $\mathbf{n}^{\mathbf{0}}$ 1.480/97. Available in: http://www.portalmedico.org.br/resolucoes/cfm/1997/ 1480_1997.htm Acessed Aug 26, 2017.

FONTANA, F.; MASSARI, M.; GIOVANNINI, L. ALFANO, G.; CAPPELLI, G. Knowledge and Attitudes Toward Organ Donation in Health Care Undergraduate Students in Italy. Transplant Proc. v.49, p.1982-1987, 2017.

GAŠPAR, M.; GLAVINA， A.; GRUBIŠIĆ, K.; SABOL, I.; BUŠIĆ, M.; MRAVAK, M. Stipetić The Oral Cavity State in Renal Transplant Recipients. Acta Stomatol Croat. v.49, p.204-213, 2015.

GOZ, F.; GOZ, M.; ERKAN, M. Knowledge and attitudes of medical, nursing, dentistry and health technician students towards organ donation: a pilot study. J Clin Nurs. v.15, p.1371-1375, 2006.

JAIN, M.; YADAY, N.R.; SHARMA, A.; SINGH, S.; JAIN, V.; KHANNA, B.; SINGH, A.; CHHIBBER, R. Promovendo o conhecimento da doação de órgãos: uma abordagem educacional. J Family Med Prim Care. v.8, p.4021-4026.

LIMA, C.X.; LIMA, M.V.B.; CERQUEIRA, R.G.; CERQUEIRA, T.G.; RAMOS, T.S.; NASCIMENTO, M.; ANDRADE, C.R.M.; CUNHA, D.G.; GARCIA, S.L.M. Organ Donation: Cross-sectional survey of knowledge and personal views of brazilian medical students and physicians. Transplant Proc. v.42, p.1466-1471, 2010

LINS, L.; BITTENCOURT, P.L.; EVANGELISTA, M.A.; LINS, R.; CODES, L.; CAVALCANTI, A.R.; PARANÁ, R.; BASTOS, J. Oral health profile of cirrhotic patients awaiting liver transplantation in the Brazilian Northeast. Transplant Proc. v.43, p.13191321, 2011.
MILLER, C.; BREAKWELL, R. What factors influence a family's decision to agree to organ donation? A critical literature review. London J Prim Care. v.10, p.103-107.

Organ transplantation in Brazil (2009-2017). Brazilian Transplantation Registry 2017; 3:1-104. Available in: http://www.abto.org.br/abtov03/Upload/file/RBT/201 7/rbt-imprensa-leitura-compressed.pdf Accessed July 26, 2018.

PESSOA, S.F.P.; BARROSO, V.S.; DUARTE, A.V.; ABREU, H.C.M.; CASTRO, B.B.A.; CARMINATTI, M.; SANDERS-PINHEIRO, H. Public Knowledge and Attitudes Toward Organ Donation and Transplantation: A Survey From a Medium-Sized Brazilian City. Transplant Proc. v.52, p.1223-1225, 2020.

REIS, F.P.; GOMES, B.H.; PIMENTA, L.L.; ETZEL, A. Brain death and tissue and organ transplantation: the understanding of medical students. Rev Bras Ter Intensiva. v.25, p.279-283, 2013.

ROBBA, C.; FOSSI, F.; CITERIO, G. Organ donation: from diagnosis to transplant. Curr Opin 79 Anesthesiol. v.33, p.146-155, 2020.

SANTOS, P.S. \& MELLO, W.R. What is the role of dentistry in organ transplants? J Oral Res. v.7, p.14, 2018.

SANTOS, P.S.S.; SOUSA, F.B.; CORACIN, F.L.; MANCUSI SOBRINHO, R.; LIMA, R.B. Oral complications associated to organ and tissue transplants: a literature review. JBT J Bras Transpl. v.12, p.1064-1069, 2009.

SANTOS, R.J.; LINS, L.; SANTOS, M.R.C.; MENEZES, M.S.; CARVALHO, F.A.R.; CARVALHO, F.M. Ethical aspects of organ transplantation from medical students' perspective: a comparative study. Rev. Bioét. v.24, p.344-354, 2016.

SIEBELINK, M.J.; VERHAGEN, A.A.E.; ROODBOL, P.F.; ALBERS, M.J.I.J.; VAN DE WIEL, H.B.M. Education on organ donation and transplantation in primary school; teachers' support and the first results of a teaching module. PLoS One. v.12, p.e0178128, 2017.

SRINIVASULA, S.; SRILATHA, A.; DOSHI, D.; REDDY, B.S.; KULKARNI, S. Influência da educação em saúde no conhecimento, atitude e práticas em relação à doação de órgãos entre estudantes de odontologia. J Educ Health Promot. v.7, p.157. 
TACKMANN, E.; KURZ, P.; DETTMER, S. Attitudes and knowledge about post-mortem organ donation amongmedical students, trainee nurses and students of health sciences in Germany. Anaesthesist. 2020. doi: 10.1007/s00101-020-00812-8. 